\title{
Criocerinae from the Ethiopian Region (Coleoptera, Chrysomelidae)
}

\author{
Hans Silfverberg
}

Silfverberg, H. 1999: Criocerinae from the Ethiopian Region (Coleoptera, Chrysomelidae). - Entomol. Fenn. 10: 209-213.

Species of Criocerinae are recorded from various parts of the Ethiopian region, particularly from Uganda; many of these species are new for one or several countries. Lema omukama sp.nov. is described from Uganda. Lema democratica Clavareau is synonymized with $L$. milleriana Wollaston. Information is given on colour variation in a number of species.

Hans Silfverberg, Zoological Museum, P.O.Box 17, FIN-00014 Helsingfors

Received 15 September 1997, accepted 1 June 1998

The Finnish Museum of Natural History has acquired a number of Criocerinae from the Ethiopian (Afrotropical) region. Besides one new species there are among these specimens several that add to the known distribution of the species, and some common species are represented in such numbers, that data on variation may be obtained.

\section{Criocerinae from Uganda}

These specimens were collected in Uganda, Kibale Forest, by Dr. Matti Nummelin during the years 1983-85. The material was collected with sweep nets in the forest, all these specimens are labelled "Uganda, W. Pr., Kibale Forest, M. Nummelin leg.", and carry additionally on labels the information mentioned in connection with each species.

The following species are reported as new for Uganda: Lema restricta Clavareau, Lema pauli Weise, Lema omukama sp.n. and Lema quadrifasciata Heinze.

\section{Sigrisma cylindrica (Klug)}

Sweep K 14A, 23.3.1985 (1 ex.).

Distribution. From Senegal to Eritrea, and to the Cape Province.

\section{Crioceris nigropunctata Lacordaire}

Sweep Pine C, 22.3 .1985 (1 ex.).

Distribution. Western, Eastern and Southern Africa.

According to Heinze \& Pinsdorf (1962) the western specimens, east to Meru, belong to a subspecies $C$. $n$. occidua Heinze, characterized by a darkened suture. This Ugandan specimen does not show any sutural darkening.

\section{Lema erythraeana Clavareau}

Sweep K 30, 20.11 .1984 (1 ex.).

Distribution. From Eritrea to Uganda and Cameroon.

This specimen has entirely dark legs (ab. interiora). 


\section{Lema dregei Lacordaire}

19.11.1983 (1 ex.); 1.12.1983 (2 exx.); Sweep Pine, 1.1.1984 (1 ex.); Sweep Pine, 14.5.1984 (2 exx.); Sweep Pine, 19.9.1984 (2 exx.); Sweep Pine, 14.5.1985 (1 ex.).

Distribution. From Cameroon and Eritrea to the Cape.

\section{Lema restricta Clavareau}

12-13.9.1983 (1 ex.); Sweep Ngogo, 27.2.1984 (1 ex.); Sweep Ngogo, 18.3.1985 (1 ex.); Sweep K 14, 16.10 .1984 (1 ex.); Sweep K 14, Dec.1984 (1 ex.).

Distribution. Previously reported from Ghana and Congo (Kinshasa) (Heinze \& Pinsdorf 1963).

\section{Lema korschefskyi Heinze}

Sweep Pine, 14.5.1985 (1 ex.).

Distribution. Known from Uganda and Congo (Kinshasa).

This specimen agrees with the description of ab. biparticollis (Heinze \& Pinsdorf 1964).

\section{Lema mulangensis Heinze}

12-13.9.1983 (1 ex.); Sweep Pine, 16.3.1984 (1 ex.); Sweep Pine, 16.12.1984 (1 ex.); Sweep Pine, 19.1.1985 (1 ex.); Sweep Pine, 14.3.1985 (1 ex.).

Distribution. Uganda, Rwanda, Congo (Kinshasa) and Ethiopia.

The hind femora are red in 3 specimens, black in 2 .

\section{Lema pauli Weise}

Sweep Pine, 17.11.1984 (1 ex.); Sweep K 14, 19.4.1985 (1 ex.); Sweep K 14C, 26.3 .1985 (1 ex.).

Distribution. Heinze \& Pinsdorf (1964) mention this species from Tanzania and from South Africa.

Two of the specimens are greenish, one is bluish.

\section{Lema fuscitarsis Jacoby}

1.12.1983 (3 exx.); Sweep Pine, 15.4.1984 (2 exx.); Sweep Pine, 19.9.1984 (3 exx.); Sweep Pine, 18.10.1984 (1 ex.); Sweep Pine, 17.11.1984 (1 ex.); Sweep Pine, 16.12.1984 (1 ex.); Sweep Pine, 19.1.1985 (3 exx.); Sweep Pine, 14.3.1985
(5 exx.); Sweep Pine, 28.4.1985 (1 ex.); Sweep Pine, 14.5.1985 (1 ex.); Pine, 1991 (1 ex.); Sweep Pine B, 18.3.1985 (1 ex.); Sweep Pine C, 22.3.1985 (1 ex.); Sweep K 14, 19.4.1985 (1 ex.); Sweep K 14, 13.9.1986 (2 exx.); Sweep K 14A, 23.3.1985 (2 exx.); Sweep K 14B, 25.3 .1985 (3 exx.); Sweep K 14C, 26.3.1985 (2 exx.); Sweep K 15, 18.12.1984 (4 exx.); Sweep K 15, 13.3.1985 (2 exx.); Sweep K 15, 8.5.1985 (1 ex.).

Distribution. From Ethiopia and Congo (Brazzaville) to the Cape.

The legs of 21 specimens are black, of 20 brownish yellow; one of the blacklegged specimens has reddish femora.

\section{Lema omukama sp.n.}

Colour piceous black, clypeus somewhat lighter brown; head behind the frontal triangle often with two reddish spots. One of the specimens has the antennae and legs yellowish brown.

Frons with a slightly elevated, very weakly punctate triangle, which is divided by a longitudinal groove in the posterior half. Antennae fairly slender, segments 5-10 slightly more than twice as long as broad.

Pronotum somewhat broader than long, anteriorly broader than posteriorly, strongly constricted; anterior corners rounded, very weakly tuberculate. Disc shining, very weakly punctate. Transverse basal depression impunctate except for a sharp pit in the middle.

Elytra moderately broad, with a strong humeral and a comparatively strong antemedial depression. Striae anteriorly strongly punctate, punctation weaker towards apex; punctures slightly elongate. Intervals flat, impunctate.

Length $4.6-5.4 \mathrm{~mm}$, width $2.1-2.4 \mathrm{~mm}$.

Holotype. UGANDA W Pr, Kibale forest, Sweep K 14C, 26.3.1985, M. Nummelin leg. Paratypes: same data except Sweep K 14, Dec.1984 (1 ex.); Sweep K 15, 1984 (1 ex.); Sweep K 30, 16.3.1985 (1 ex.). Types in the Finnish Museum of Natural History.

Etymology. Omukama is the title of the traditional Tooro ruler; the Kibale forest is within Tooro.

This species falls within the Lema pauperata group because of the structure of its head and pronotum. Within that group it is immediately recognizable by its colour. Of the four specimens studied one, the holotype, lacks entirely the reddish spots behind the frontal triangle, in the other 
three specimens these spots are of varying size, at the most together almost the size of the triangle.

\section{Lema quadrifasciata Heinze}

1.12.1983 (1 ex.); Sweep Pine, 15.4.1984 (1 ex.); Sweep Pine, 18.10.1984 (1 ex.); Sweep Pine, 16.12 .1984 (2 exx.); Sweep K 14, 16.11.1984 (1 ex.); Sweep K 14, 19.4.1985 (1 ex.); Sweep K 14A, 23.3.1985 (2 exx.); Sweep K 15, 1984 (1 ex.); Sweep K 15, 20.10.1984 (1 ex.); Sweep K 15, 18.12.1984 (1 ex.).

Distribution. From Kenya to Congo (Kinshasa) and Zambia; Heinze \& Pinsdorf (1964) do not mention Uganda for this species.

One of the specimens lacks entirely the posterior elytral black band, in two this band is reduced to fairly indistinct spots; the legs are yellowish in 5 specimens and black in 7.

\section{Lema reducteapicalis Pic}

Sweep K 15, 18.11 .1984 (1 ex.).

Distribution. From Ghana to Uganda and Congo (Kinshasa).

This specimen has reddish antennae and black legs with brownish tarsi.

\section{Lema rubricollis Klug}

12-13.9.1983 (1 ex.); 9.10.1983 (1 ex.); Sweep Pine, 18.10.1984 (1 ex.); Sweep Pine, 14.2.1985 (1 ex.); Sweep Pine, 28.4.1985 (2 exx.); Sweep Pine, 12.9.1986 (1 ex.); Sweep K 14, 12.4.1984 (2 exx.); Sweep K 14, Dec.1984 (1 ex.); Sweep K 14A, 23.3.1985 (1 ex.); Sweep K 14C, 23.3.1985 (1 ex.); Sweep K 15, 1984 (2 exx.); Sweep K 15, 18.12.1984 (1 ex.); Sweep K 15, 15.3.1985 (1 ex.); Sweep K 15, 12.9 .1986 (1 ex.).

Distribution. From Guinea to Uganda and Angola.

Two of the specimens have head and pronotum red, in the rest the pronotum is black and the head mostly black.

\section{Lema kerremansi Clavareau}

1.12.1983 (1 ex.); 2.12 .1983 (1 ex.); Sweep Pine, 16.3.1984 (1 ex.); Sweep Pine, 15.4.1984 (1 ex.); Sweep Pine, 17.11.1984 (2 exx.).

Distribution. From Equatorial Guinea to Congo (Kinshasa) and Uganda.

\section{Additional faunistic notes}

The materials collected by Dr. Rauno Linnavuori primarily in Western and Central Africa include a number of Criocerinae. As some of the countries, where he travelled, are still fairly poorly known in entomological respect, this material presents several new country records. Also some specimens collected in the Cabo Verde Islands by H. Lindberg and $\mathrm{S}$. Panelius add to our knowledge.

\section{Lilioceris livida (Dalman)}

Nigeria, NW St., Birni Yauri - Rijau, 23.7.1973, R. Linnavuori.

Distribution. West Africa, east to Tanzania.

\section{Lilioceris latipennis (Clark)}

Ghana, nr. Bekwai, 17.9.1973, R. Linnavuori; Ghana, nr. Foso, 17.9.1973, R. Linnavuori.

Distribution. West Africa, east to Cameroon.

\section{Lilioceris aestivalis (Clark)}

Nigeria, W. St., Ife, 7-8.7.1973, R. Linnavuori.

Distribution. From Senegal to Congo (Kinsha$\mathrm{sa})$.

\section{Lilioceris africana (Jacoby)}

Nigeria, MW. St., Benin - Ore, 5-6.7.1973, R. Linnavuori.

Distribution. From Guinea to Congo (Kinshasa).

\section{Lema foraminosa Lacordaire}

Nigeria, NE. St., Gembu, 21-22.8.1973, R. Linnavuori.

Distribution. Previously recorded from eastern Africa, Eritrea to Congo (Kinshasa) and Zimbabwe. This find is the westernmost so far recorded.

\section{Lema hottentota Lacordaire}

Central African Republic, La Maboke, 6-9.6.1973, R. Linnavuori.

Distribution. West, Central, East and South Africa. 


\section{Lema cephalotes Lacordaire}

Yemen, Hudaydah, Zahid, 20.5.1992, R. Linnavuori.

Distribution. From Senegal to Cameroon, Ethiopia and Yemen. This is the only species of Criocerinae so far recorded from Yemen (Medvedev 1996).

\section{Lema humeralis (Guérin-Ménéville)}

Ghana, nr. Téma, 16.9.1973, R. Linnavuori.

Distribution. From Guinea to Uganda and Congo (Kinshasa).

\section{Lema pauperata Lacordaire}

Nigeria, W.St., Ife, 7-8.7.1973, R. Linnavuori.

Distribution. Previously recorded from Guinea, Cameroon and Equatorial Guinea.

\section{Lema milleriana Wollaston, 1867}

Lema democratica Clavareau, 1909 (syn.nov.).

Ins. Cabo Verde, S. Antäo, Pombas, 23-26.12. 1953, Panelius (5 exx.); ibid., Lindberg (4 exx.); Antäo, Campo de Cäo, 30.12.1953, Lindberg (14 exx.); Brava, Nova Cintra, 22.2.5.3.1954, Lindberg (1 ex.).

The elytra are black with more or less extensive testaceous patterns. Among the specimens from Pombas, one has a complete anterior testaceous transverse band, reaching the side margin and across the suture. In two specimens the band reaches across the suture, but does not reach the side margin. In four specimens the band has been reduced to a separate spot on each elytron, and in two specimens the anterior band has disappeared completely. Among the specimens from Campo de Cäo the corresponding numbers are 1, 1, 6 and 6 . The specimen from Brava has a complete anterior band. In all specimens the elytral apex is testaceous.

The colour of the head also shows considerable variation. In the two palest specimens the head is yellowish red, with only a black transverse band behind the frontal triangle. In most specimens the triangle is more or less black, from specimens with the base black over specimens with only the tip reddish to four specimens with a completely black triangle; in the darkest specimens the black col- our also reaches the eye margin. In the pronotum at least each of the corners is covered by a black spot, and the anterior margin carries one; among the Santo Antäo specimens eight have such a pattern. Six Santo Antäo specimens have the anterior margin entirely black, in six further ones the anterior margin is entirely black and there is a connection between the spots on the anterior and the posterior corners. In two specimens the pronotum is almost entirely black, with merely some reddish colour near the hind margin, and in one specimen it is entirely black. The specimen from Brava has the five spots separate.

The legs are testaceous, the tarsal segments slightly darkened at apex. No variation was observed in their coloration.

Geisthardt (1984), who had studied the type material, observed that L. milleriana and L. democratica were structurally similar, and differed only in coloration; he suggested that they might actually be conspecific. The material from $S$. Antäo shows a transition from one colour morph to another, thus confirming the suggested synonymy.

This species is apparently endemic to the Cabo Verde Islands. It has previously been reported from S. Vicente and Santiago (as L. milleriana) and S. Nicolau (as $L$. democratica). The colour variation might be different on different islands.

L. milleriana falls within the Lema pauperata group, as defined by Heinze \& Pinsdorf (1964). It is quite similar to Lema quadrifasciata Heinze, but is slightly larger and has a more extensive black coloration; in particular $L$. quadrifasciata is not known to have spots on its pronotum, and its head should not have black coloration.

\section{Lema quadripartita Lacordaire}

Chad, Bebedja, 28-31.5.1973, R. Linnavuori.

Distribution. Previously recorded from Senegal, Togo, Nigeria, Cameroon, Congo (Kinshasa) and Uganda.

\section{Lema rubricollis Klug}

Central African Republic, La Maboke, 6-9.6.1973, R. Linnavuori.

Distribution. see above. 


\section{Lema affinis Clark}

Cameroon, E, Dimako - Abong Mbang, 13.6. 1973, R. Linnavuori.

Distribution. From Togo to Uganda and Congo (Kinshasa).

\section{Lema nigriventris Gerstaecker}

Nigeria, NE St., Yola, 25.8.1973, R. Linnavuori (2 exx.). Chad, Deli, 30.5.1973, R. Linnavuori.

Distribution. From Senegal to Ethiopia and South Africa.

\section{Lema aperta Lacordaire}

Chad, Bebedja, 28-31.5.1973, R. Linnavuori.

Distribution. Previously recorded from Senegal, Guinea, Côte d'Ivoire, Säo Tomé e Príncipe and Congo (Kinshasa).

\section{Oulema raffrayi (Chapuis)}

Nigeria, NC St., Yengre, 4.8.1973, R. Linnavuori; NE St., Yola, 25.8.1973, R. Linnavuori (4 exx.). Chad, Bebedja, 2021.5.1973, R. Linnavuori (2 exx.).

Distribution. From Senegal to Ethiopia and South Africa.

\section{Oulema punctatissima (Heinze)}

Burkina Faso, Ouagadougou, 3-5.11.1973, R. Linnavuori. Cameroon, SW, Beta beach, 19-20.6. 1973, R. Linnavuori.

Distribution. Previously recorded from Sierra Leone, Guinea, Liberia, Ghana, Nigeria and Congo (Kinshasa).

\section{Incisolema cylindricollis (Lacordaire)}

Chad, Bebedja, 28-31.5.1973, R. Linnavuori (9 exx.).

Distribution. Previously recorded from Senegal, Nigeria, the Central African Republic, Congo (Brazzaville) and Congo (Kinshasa); ? Ethiopia.

\section{References}

Geisthardt, M. 1984: Zur Kenntnis der Käfer der Kapverden. Ergebnisse der Sammelreise 1982 (Insecta: Coleoptera). - Cour. Forsch.-Inst. Senckenberg 68: 57-94.

Heinze, E. \& Pinsdorf, W. 1962-64: Die Criocerinen Afrikas (Col. Chrysomelidae). - Entomol. Arb. Mus. Frey 13: 156-270, 14: 252-372, 15: 334-569.

Medvedev, L. 1996: The Chrysomelidae of Arabia. — Fauna of Saudi Arabia 15: 211-263. 